\title{
Research Paper Growth pattern and share of lead bank (Bank of India) in Ratnagiri district of Maharashtra
}

\author{
口 P.S. KAMBALE, A.C. DEORUKHAKAR AND M.G. LAGARE
}

See end of the paper for authors' affiliations

Correspondence to :

\section{P.S. KAMBALE}

Department of

Agricultural Economics,

Dr. Balasaheb Sawant

Konkan Krishi Vidyapeeth

Dapoli, RATNAGIRI (M.S.)

INDIA

Email:Kambalepooja2238

@ gmail.com

\section{Paper History :}

Received : 14.08.2014;

Revised : 26.12 .2014

Accepted : 12.01 .2015
ABSTRACT : Fourteen nationalized banks, state bank groups and three private sector banks were designated as lead banks. All the districts in the country and the union territory of Goa, Daman and Diu were distributed among the lead banks to play the role of catalytic agents for the economic development of the district concerned and the promotion of development through the medium of banks. In present study, the linear growth rate of lead bank in parameters like total deposits, total advances, total priority sector advances, agricultural advances, OPS advance, PMRY advances, other Government programmes advances and total Government programmes advances were positive and significant at five per cent level. The compound growth rate of lead bank in parameters like total branches, total deposit, total advance, total priority sector, agricultural, small scale industry, other priority sector and total government programme were positive and significant at five per cent level. The growth parameter of total branches, total deposits and total advances showed highly significant. Share of the lead bank in total credit disbursement showed that, there was adequate number and spread of branches of the lead bank (Bank of India) operating in the district. Share in total advances had increased upto 2007-08 but had shown decreasing trend during the last five years, is a matter of concern for future development of the district.

KEY WORDS : Growth, Share, Lead bank

HOW TO CITE THIS PAPER : Kambale, P.S., Deorukhakar, A.C. and Lagare, M.G. (2015). Growth pattern and share of lead bank (Bank of India) in Ratnagiri district of Maharashtra. Internat. Res. J. Agric. Eco. \& Stat., 6 (1) : 39-43. 